\title{
PODNĚTY K HLUBŠÍMU PROMÝŠLENÍ POMĚRU MEZI DOGMATICKOU A MORÁLNÍ TEOLOGIÍ
}

\author{
CTIRAD VÁCLAV POSPÍŠIL
}

K aždému, kdo se jen trochu orientuje v teologii, by mělo být zřejmé, že otázka poměru mezi dogmatickou a morální teologií rozhodně nepatří mezi otázky okrajového významu. Když se autor konfrontuje se značnou komplexností dané problematiky, ${ }^{1}$ uvědomuje si, že v př́spěvku tohoto typu má šanci pouze upozornit na základní styčné body a třecí plochy mezi oběma disciplínami a naznačit jejich hlubší význam pro inteligenci křestanské existence. Při práci na této studii jsem si nemohl neuvědomit, že nastolená problematika se pod různými hávy relativně často projevovala $\mathrm{v}$ mé předchozí reflexi, takže to pro mne byla mimo jiné rovněž př́ležitost ke shrnutí, opětnému promyšlení, projasnění a určitému rozvinutí toho všeho. Právě řečené jenom dotvrzuje, že se jedná o otázku neopomenutelnou, klíčovou a velmi komplexní.

Na první pohled se zdá, že k danému problému lze přistupovat bud' z hlediska dogmatiky, nebo morálky. Hermeneutická kázeň mi tudíž velí, abych na tomto místě důrazně předeslal, že nastolené téma nahlížím především z hlediska své vlastní specializace, jíž je dogmatická teologie, přednostně christologie, soteriologie, trinitologie a hermeneutika mystéria. Oprávněnost tohoto př́stupu a jeho nosnost bude však třeba v průběhu našeho společného usilování hlouběji ospravedlnit a odůvodnit.

1 Paralelou poměru dogmatická teologie - morální teologie je zcela zásadní otázka, jíž se zabývají mnozí filosofové v posledních desetiletích, totiž otázka poměru mezi metafyzikou na jedné straně a etikou na straně druhé. Na tomto místě pouze připomínáme: LÉVINAS, Emmanuel. Totalita a nekonečno: (esej o exterioritè). 1. vydání. Praha: OIKOYMENH, 1997; ŘÍHA, Karel. Identita a relevance. 1. vydání. Svitavy: Trinitas, 2002. 
Nyní přistoupíme k představení hlavních podtémat, do nichž je studie rozčleněna. $V$ prvním bodu jde o to, že mezi oběma teologickými disciplínami panuje pomèr vzájemného partnerství a nutného doplňování, jež dodává jejich výrokům hlubší odůvodněnost, smysluplnost a věrohodnost. V druhém bodu se dotýkáme otázky poměru morální teologie k době, kultuře a určité formě vědeckého poznání. Nezapomínejme, že věda je společenským jevem, a její statut i pojímání se proto v dějinách nevyhnutelně mění. S tématem kultury je nevyhnutelně spjat ne právě jednoznačný pojem přirozenosti a následně také palčivý problém valence empirických údajů prrírodních a antropologických věd v teologické antropologii a přednostně v morální teologii. Třetí bod pojednává především o paradigmatickém poměru mezi Kristem a zákonem, s čímž souvisí vážná otázka spásonosné hodnoty předpisů zákona či určité morálky. Čtvrtý bod nás přivádí k teologické valenci morálních předpisů, tedy k tomu, jaký Bůh či „bůh“ se vlastně v těchto normách zračí. Pátý bod úzce souvisí s předchozím, protože se $\mathrm{v}$ něm nabízejí podněty $\mathrm{k}$ budoucímu vypracování skutečné trinitární morální teologie. Tato pasáž ale souvisí i se všemi ostatními a představuje jakési „srdce“ celé studie, v němž dospíváme k poslednímu odůvodnění těsné spojitosti mezi dogmatickou a morální teologií na základě tajemství Nejsvětější Trojice. V šestém bodu na způsob jakéhosi epilogu předkládám podle mého soudu stále aktuální Bonaventurovo schematické znázornění poměru mezi oběma inkriminovanými disciplínami, které nám dovoluje jasněji si uvědomovat přesah moudrosti nad „pouhou“ vědeckostí uzavřenou v mezích určité specifické metodologie.

\section{Perichoretické partnerství dogmatické a morální teologie}

Občas se setkáme s nostalgickými výroky o tom, že ještě vrcholná scholastika nerozdělovala teologii na dogmatickou a morální. Svědčí o tom např́ḱlad struktura Sentencí Petra Lombardského, v nichž se obě tematiky vzájemně střídají a prolínají, takže zatímco kupř́íkladu první polovina třetí knihy je věnována christologii a soteriologii, její druhá část pojednávala o ctnostech. ${ }^{2}$ Jenomže i v oné prapůvodní jednotě platilo, že autoři rozlišovali teorii spjatou s nazíráním Božích pravd (contemplatio) a praktický rozměr teologického myšlení, jehož předmětem byla správnost a spásonosná hodnota lidského jednání. Zejména reprezentanti

2 Srov. MAGISTRI PETRI LOMBARDI. Sententiae in IV libris distinctae II - liber III et IV. Grottaferrata, Romae: Collegii S. Bonaventurae Ad Claras Aquas, 1981. 
františkánské školy kladli velký důraz na praktické zacílení celé teologie. ${ }^{3}$ To, co dnes nazýváme „dogmatická teologie“, bylo díky řečenému jednak východiskem morální teologie, jednak v ní nacházelo své vyústění jako v praktickém uskutečňování velkého tajemství spásy, které dává celé teologii smysl. Ve vzájemném poměru mezi oběma složkami scholastické reflexe a dnešními disciplínami tedy rozhodně neexistovala, a ani dnes by neměla existovat, nadřazenost či podřazenost, nýbrž pouze rozlišenost a kolegiální komplementarita.

Ponechme nyní stranou důvody, jež vedly na počátku novověku k postupně stále zřetelnějšímu oddělování dvou samostatných teologických disciplín. ${ }^{4}$ Dlužno zároveň poznamenat, že ono rozdělení nebylo v minulých staletích tak dramatické jako dnes, nebot teologové dokázali na poměrně solidní úrovni zvládat obojí. Zároveň je ale třeba přiznat, že postscholastická doba manuálu se i v souvislosti $\mathrm{s}$ dobovým klimatem osmnáctého a devatenáctého století bohužel vyznačovala sklonem k nadhodnocování, ba absolutizaci morálky na úkor dogmatického nazírání Božích tajemství. ${ }^{5}$ Zejména v průběhu minulého století navíc došlo k tomu, že se stalo holou nezbytností, aby se teologové vydali cestou stále užší specializace, což sice jednoznačně prospělo rozvoji dogmatické reflexe, nicméně zároveň vcelku pochopi-

3 Srov. např. POSPÍŠIL, Ctirad V. Základní christologické inspirace v díle Jana Duns Scota a jejich aktualita. In BENEŠ, Petr Regalát - HLAVÁČEK, Petr (ed.). Historia Franciscana II. 1. vydání. Kostelní Vydří: Karmelitánské nakladatelství, 2005, s. 9-33. Srov. např. ANGELINI, Giuseppe. Teologia morale fondamentale: Tradizione, Scrittura e teorie. 1. vydání. Milano: Ed. Glossa, 1999, s. 180nn.

5 Tendence $\mathrm{k}$ redukci teologie na morálku se do značné míry projevují například v díle: DOBROVSKÝ, Josef. Přednášky o praktické stránce $v$ křestanském náboženství. 1. vydání. Praha: Ed. Volf, J. - Volf, M. B. - Vraštil, J., 1948. Velmi dobře shrnuje obsah díla Josef Táborský, když vypovídá o zásadách správného náboženství podle Dobrovského: „Bůh je shovívavý, láskyplný, neskonale moudrý a dobrotivý Otec, v jehož bytostném zájmu je, aby všichni lidé došli k blaženosti. K tomu svým zjevením podává návod a otvírá cestu. Člověk není radikálně zkažený, je schopen zdokonalování. Jeho spolupůsobení na cestě k blaženosti je nezbytné. Pravé náboženství vede k mravní praxi a radosti ze života, nikoli k obřadnictví, formalismu, strachu a sklíčenosti. Pozemský život je sice přípravou na věčný život, není však slzavým údolím, nýbrž jedinečnou příležitostí k mravnímu zdokonalování. I v náboženských otázkách je třeba důsledně užívat rozumu." TÁBORSKÝ, Josef. Reformni katolik Josef Dobrovský. 1. vydání. Brno: L. Marek, 2007, s. 92. Dlužno však podotknout, že ve věku zralosti, tedy po padesátém roku života, se i u Dobrovského objevoval opětný příklon k mystériu (srov. tamtéž, s. 118-125). Druhým př́kladem značné redukce křestanství na morálku mohou být mariánské promluvy A. Krombholze z první poloviny devatenáctého století, které ve druhé části své monografie analyzuje VEVERKOVÁ, Kamila. Dílo Antona Krombholze a jeho význam pro reformní teologické myšleni v Čechách. 1. vydání. Brno: L. Marek, 2004. 
telně vedlo k dalšímu vzájemnému vzdalování se obou disciplín, takže dogmatická teologie donedávna ztrácela ze zřetele své zacílení k praxi a morální teologii zase hrozilo, že bude předkládat požadavky, aniž by je dokázala propojovat s tajemstvím víry, v němž se také nalézá jejich nejhlubší odůvodnění. ${ }^{6}$

O oddělování obou disciplín svědčí i skutečnost, že pojednání o dějinách teologie bylo až doposud vnímáno převážně, ba výlučně jako dějiny dogmatické případně fundamentální teologie. Stále jasněji si proto uvědomujeme potřebu pracovat na detailnějším a důkladnějším zpracování dějin morální teologie. ${ }^{7} \mathrm{~V}$ dané souvislosti určitě není bez významu, že výrazná většina dokumentů Mezinárodni teologické komise byla prozatím věnována dogmatickým otázkám. ${ }^{8}$

Hledáme-li pomèr mezi dogmatickou a morální teologií, nebude zřejmě nevhodné připomenout, že dogmatická teologie $\mathbf{v}$ posledních desetiletích stále výrazněji hledá svůj poměr ke každodennímu životu, k praxi či $\mathrm{k}$ ortopraxi. ${ }^{9}$ Vzhledem k tomu, že zmíněná relace se popisuje na základě

$6 \quad$ „... v průběhu staletí vznikla velká distance mezi morálními imperativy, které se předkládají věřícím, a evangelijním zakořeněním těchto požadavků. Každopádně platí, že je dnes velmi naléhavé nově formulovat poměr mezi normami a jejich evangelijními motivacemi, aby tak bylo mnohem srozumitelnější, že předkládání morálních norem úzce souvisí s předkládáním evangelia.“ PONTIFICIA COMMISSIONE BIBLICA. Bibbia e morale, čl. 55. <http://www.vatican.va> [2009-03-14].

7 Práce pojednávající o dějinách morální teologie či etiky existují: srov. např. VEREECKE, Louis. Storia della teologia morale. In COMPAGNONI, Francesco - PIANNA, Giannino - PRIVITERA, Salvator (ed.). Nuovo Dizionario di Teologia Morale. Milano: Ed. Paoline, 1990, s. 1314-1338 - autor přináší také poměrně obsáhlou bibliografii specializovaných studií. Dále je třeba uvést: VIDAL, García Marciano. Nuova morale fondamentale. 1. vydání. Bologna: Ed. Dehoniane, 2004, s. 255-518 - autor přináší četné bibliografické údaje. Zároveň je ale třeba konstatovat, že tyto př́klady potvrzují, že důkladnější a detailnější zpracování dějin morální teologie, které by bylo srovnatelné s dějinami systematické teologie nebo s dějinami dogmatu, leží před odborníky jako poměrně naléhavý úkol.

8 Srov. COMMISSIONE TEOLOGICA INTERNAZIONALE. La morale cristiana e le sue norme (1974). In ID. Documenti 1969-2004. 1. vydání. Bologna: ESD, 2006, s. 65-94. Nepřímo se morální teologie týká také dokument: COMMISSIONE TEOLOGICA INTERNAZIONALE. Dignita e diritti della persona umana (1983). In ID. Documenti 1969-2004, s. 255-278. Do oblasti morální teologie spadá chronologicky prozatím poslední dokument: COMMISSIONE TEOLOGICA INTERNAZIONALE. Alla ricerca di un'etica universale: nuovo sguardo sulla legge naturale (2009). <http:// www.vatican.va>. K tomu je třeba dodat, že například dokument: MEZINÁRODNí TEOLOGICKÁ KOMISE. Společenství a služba. 1. vydání. Kostelní Vydří: Karmelitánské nakladatelství, 2005, obsahuje v souvislosti se svým bytostně antropologickým zaměřením také některé pasáže věnované bioetice. Celkový počet dokumentů MTK je k dnešnímu dni 23.

9 Termínu rozumíme zejména ve smyslu pravá svatost. Nejde tedy pouze o sociální spravedlnost, jak se někdy zúženě pojímá význam tohoto výrazu. 
schématu hermeneutického kruhu, ${ }^{10}$ zdá se být nanejvýš vhodné, aby se poměr mezi ortodoxií (dogmatika) a ortopraxí (morální teologie, spiritualita) pojímal na základě stejného paradigmatu. ${ }^{11}$

S tématem relace mezi ortodoxií a ortopraxí určitě velmi úzce souvisí poměr mezi obsahem víry (fides quae creditur), který odpovídá převážně kompetenčnímu poli dogmatické teologie, a vírou jako darem i jako svobodným rozhodnutím (fides qua creditur), což spadá pochopitelně převážně do kompetence morální teologie a spirituality. Je-li každému dospělému křestanovi zřejmé, že existuje jenom jedna víra (srov. Ef 4,4-6) a že právě uvedené rozlišování mimo její rámec prostě nedává smysl, pak z toho vyplývá, že ve skutečnosti existuje jenom jedna teologie jakožto věda jediné víry, ${ }^{12}$ a proto rozlišení na dogmatickou a morální teologii je smysluplné jedině za předpokladu, že nedochází k jejich oddělování. Zároveň se projasňuje, že i mezi fides quae creditur na jedné straně a fides qua creditur na straně druhé platí vzájemná souvislost jako v hermeneutickém kruhu. S tím souvisí, jak uvidíme níže, také vzájemné prostupování obou komponentů, které se vzájemně ovlivňují a podmiňují, což můžeme vnímat jako analogii perichoreze.

Jakmile začneme rozumět významu zjevených pravd víry pro praxi, pro autentický křestanský život, vnímáme je hermeneuticky korektně, nebot tyto pravdy byly zjeveny nebo definovány nikoli jako do sebe uzavřené teoretické výroky, nýbrž jako směrnice a měřítka pro autentický život víry. Opačně platí, že pokud neumíme uchopit právě naznačený

10 Srov. např. ACERBI, Antonio. Ortoprassi. In BARBAGLIO, Giuseppe - DIANICH, Severino (ed.). Nuovo dizionario di teologia. 1. vydání. Milano: Ed. Paoline, 1988, s. 1018-1045, zde 1023.

11 Srov. POSPÍŠIL, Ctirad V. Hermeneutika mystéria: struktury myšlení v dogmatické teologii. 1. vydání. Kostelní Vydří - Praha: Karmelitánské nakladatelství - Krystal O.P., 2005, s. 127.

12 Na tomto místě si dovolím upozornit na určitou strukturální souvislost mezi bipolárně paradoxálním paradigmatem mravní ctnosti na jedné straně a stejným bipolárně paradoxálním paradigmatem $\mathrm{v}$ zásadě všech pravd nadpřirozené víry na straně druhé. Vymezení ctnosti víry, což by odpovídalo fides qua creditur, dvěma pro svou částečnost nepřijatelnými extrémy (lehkověrnost, pověrečnost - radikální skepse, absolutizace lidské racionality a empirie) tedy úzce souvisí s vymezením pole legitimního teologického pluralismu, které je opět vymezeno dvěma extrémy, jež pro jejich nedostačující jednostrannou částečnost označujeme slovem „hereze“, což by odpovídalo fides quae creditur. Posledním kořenem této stále se opakující struktury je zcela evidentně tajemství Nejsvětější Trojice jako paradox jednoty v rozličnosti a rozličnosti $\mathrm{v}$ jednotě. Jak pole vymezené pro vlastní interpretaci ctnosti, tak interval legitimního teologického pluralismu je proto jednak výrazem jednoty v rozličnosti, jednak prostorem odpovědné a tvůrčí svobody Božích synů a dcer. Katolicita tudíž rozhodně není totalitní uniformitou ani co do teologického mínění, ani co do spirituality a pojetí ctnosti jako výrazu mravnosti. 
rozměr zjevených pravd, nemůžeme jim porozumět $v$ tom duchu, $v$ němž byly vyjádřeny. Jakmile začne věřící reflektovat pravdy víry uvedeným způsobem, může navíc právě na základě vlastní zkušenosti víry dospět k určité vnitřní a intersubjektivní kvaziverifikaci jejich vlastní vypovídací hodnoty. ${ }^{13}$ Do hry tak vstupuje i předpolí dogmatické teologie, tedy fundamentální teologie se svým zájmem o prokazování věrohodnosti věřeného. Díky propojování teologických disciplín formou paradigmatu hermeneutického kruhu dochází tudíž k tomu, že dogmatika i morálka si vzájemně skýtají hlubší motivy věrohodnosti. Jde jednak o odhalování onoho nejhlubšího „proč“ morálního „musíme, měli bychom“, jež se neopírá pouze o vnější autoritu, nýbrž o porozumění, jednak o hlubší projasňování praktického zacílení dogmatické teorie. ${ }^{14}$

Tento praktický rozměr dogmatické teologie je bytostně důležitý pro kvalitu dogmatiky samotné. I ona totiž může upadnout do dogmatického „právničení“ či „legalismu“, do verbalistických ekvilibristik odtržených od života. Otřásl jsem se, když se jednou kolega zabývající se spiritualitou vyslovil o určité ožehavé záležitosti: „Dogmaticky to sice nejde, ale z hlediska duchovního života je to možné.“ Teologovi by každopádně mělo být jasné, že když něco nejde dogmaticky, nemůže to jít ani spirituálně, pokud ovšem spiritualitou nemíníme anarchii emocí a módních trendů bez solidnějšího odůvodnění na základě intelektu osvíceného vírou. Později jsem si však uvědomil, že onen starší kolega měl na mysli poněkud jinou dogmatickou teologii nežli já. Není to totiž tak dávno, co určitý typ manualistické teologie výrazně ztrácel vazbu s praxí, takže například téměř nikdo nevěděl, k čemu vlastně je trinitární teologie. ${ }^{15}$ Nesmíme se proto podivovat, když starší kolegové někdy mívají se slovem „dogmatika“ spojeny pocity poněkud smíšené. Ukazuje se, že dogmatika, ačkoli je východiskem morální teologie a spirituality, nemůže být bez těchto disciplín plně sama sebou a opravdu důstojně naplňovat své poslání.

13 POSPÍŠIL, Ctirad V. Hermeneutika mystéria, s. 126.

14 Ve filosofické reflexi se setkáváme s problematikou poměru mezi metafyzikou a etikou, která vykazuje překvapivé analogie námi zkoumaného poměru mezi dogmatickou a morální teologií. Karel Říha dospívá k závěru, že ontologie a etika se uzásadňují vzájemně: „Metafyzika a etika jako otázka bytí a otázka významu se ve své protichůdnosti shodují a navzájem podmiňují. Bytí v plném smyslu je bytí osobní. V něm se identita a relevance, bytí jako předložené a bytí jako uložené, ukazují jako dva momenty shodné i odlišné, udržující se ve vznášivé rovnováze.“ ŘíHA, Karel. Identita a relevance, s. 119; srov. s. 93.

15 Srov. POSPÍŠIL, Ctirad V. Jako v nebi, tak i na zemi: náčrt trinitární teologie. 1. vydání. Kostelní Vydří - Praha: Karmelitánské nakladatelství - Krystal O.P., 2007, s. 53-61. 
Vrat'me se ale k paradigmatu hermeneutického kruhu. Jak již bylo naznačeno, jde tu nejen o v jistém slova smyslu vnější poměr dvou kompaktních a „neprostupných“ entit, nýbrž také a možná především o poměr vzájemného prostupování, který můžeme vzhledem k trinitárnímu a christologickému základu daného pojmu analogicky definovat jako „perichoretický“. To znamená, že morální teologie je nevyhnutelně přítomna v dogmatické a naopak, ${ }^{16}$ což je nevyhnutelně spjato s postojem evangelijní „chudoby“ teologa vzhledem k předmětu studia, jímž je tajemství víry a křestanského života, a následně také k vlastní disciplíně, již si nesmí přivlastňovat jako svůj výlučný majetek. ${ }^{17}$ Morální teolog tedy ze svého vlastního hlediska bude mluvit do otázek antropologických, christologických, soteriologických, charitologických, ${ }^{18}$ trinitologických, ${ }^{19}$ které bud' zodpovědně reflektuje, a tak dělá dobrou morální teologii, anebo nereflektuje, pročež výsledek jeho snahy nemůže být hodnocen jako křestanská morálka v pravém slova smyslu. Opačně ale zase bude platit, že dogmatický teolog se bude moci a někdy i muset vyjadřovat k otázkám doposud považovaným za hájemství morální teologie a etiky. Zároveň ale platí, že perichoreticky vnímaný pomèr mezi oběma disciplínami nás důsledně chrání před tendencí pohlcovat jednu disciplínu tou druhou. V Nejsvětější Trojici je přece každá osoba sama sebou, i když důsledně přebývá v ostatních dvou a ostatní dva zase v ní. Perichoreze je dokonalá jednota v rozličnosti, jednota spjatá s nejhlubší úctou k identitě druhé-

16 Ačkoli Marciano Vidal García neužívá přímo slova „perichoreze“, když hovoří o poměru mezi náboženstvím, teologií a etikou, dospívá $\mathrm{k}$ čemusi velmi obdobnému jako my, když hovoří o příbytku. Etika, náboženství a teologie jsou si vzájemně příbytkem. Srov. VIDAL GARCÍA, Marciano. Nuova morale fondamentale, s. 9-12.

17 Na tomto místě si dovolím podotknout, že vlastnický poměr k pravdám víry a křestanského života je silně znevěrohodňujícím momentem vydávaného svědectví, protože implikuje silnou deformaci na rovině fides qua creditur, což zase vede ke snižování transcendentních tajemství, která se až idolatricky identifikují s vlastními výpověd'mi, a to je ideologizační deformace na rovině fides quae creditur. Jaký div, když v pozadí stojí idolatrie vlastního „Já“. Představitelé zvláště některých spiritualit si musí dávat velmi bedlivě pozor na v posledku tragikomickou majetnicko-mocenskou inklinaci vystupovat jako vlastníci dogmatiky a morálky, př́padně spirituality. Pravda a Duch se přece nevlastní, a proto se také vymykají a v konečném důsledku vysmívají každé ideologizaci.

18 Rozhodně není bez významu, že v tomistickém pojetí se pojednání o milosti obvykle řadí do oboru morální teologie, a nikoli do teologie dogmatické.

19 Př́ikladem je tu opět vynikající a v určitém ohledu také průkopnická práce věhlasného španělského morálního teologa, který ve své nové fundamentální morálce pojednává obšírně o dogmatických, přesněji vzato antropologických, christologických, pneumatologických a trinitárních východiscích morální teologie. Srov. VIDAL GARCÍA, Marciano. Nuova morale fondamentale, které si podle mého soudu opravdu zasluhuje, aby bylo přeloženo do češtiny. 
ho, jejíž respektování a přijetí je úzce spjato s rozkvětem vlastní identity. Řečeno jinak, místo sebestředného a nezřídka komického úsilí o iluzorní nadřazování vlastní disciplíny té druhé se stále učíme dialogu a „evangelijní chudobě“, nebot' o tématu, jímž se zabývám v kontextu své disciplíny, může zcela po právu vypovídat ten druhý z jiného zorného úhlu v rámci svého oboru. Navíc by mělo být zřejmé, že $\mathrm{v}$ perichoretickém poměru jeden není pouze partnerem toho druhého, nýbrž také součástí jeho vlastní identity, a proto dogmatika bytostně potřebuje morální teologii k tomu, aby byla sebou, stejně jako morální teologie, pokud je skutečnou teologií, zase potřebuje teologii dogmatickou jako nevyhnutelnou součást sebe samé. Pohlcovat toho druhého by tudíž v posledku znamenalo „likvidovat" sebe samotného.

Na závěr této první části je třeba podotknout, že právě předložené úvahy o vzájemném poměru obou disciplín patří nejen do tohoto prvního bodu, nýbrž vzhledem k paradigmatu perichoreze v jistém slova smyslu rovněž do klíčového pátého podtématu, kde se předkládají podněty pro vypracování trinitární morální teologie.

\section{Imanence a transcendence morální teologie vzhledem ke světu a kultuře}

Platí-li, že teologie je setkáním zjevení přijímaného a prožívaného vírou na jedné straně a určitou kulturou a filosofií na straně druhé, pak v oblasti morální teologie se bude jednat přednostně o setkání zjevení s filosofickou etikou a empirickými údaji příslušných věd o člověku. ${ }^{20}$ Mělo by být pochopitelné, že zde stejně jako všude jinde v teologii hrozí podřazování zjevené pravdy kultuře, filosofii, určité „přirozené“ etice, což je jedno ze základních paradigmat hereze. ${ }^{21}$ Při této manipulaci se zjevením totiž dochází k tomu, že se vytrácí otevřenost transcendenci, a myšlenkový konstrukt tohoto typu nevyhnutelně končí jako ideologie, tedy idolatrie do sebe uzavřené racionality (cor curvatum in se).

20 V dané souvislosti se hovoří o tak zvaném „kantismu“. Srov. PRIVITERA, Salvatore. Epistemologia morale. In COMPAGNONI, Francesco - PIANA, Giannino - PRIVITERA, Salvatore (ed.). Nuovo Dizionario di Teologia Morale, s. 325-349.

21 „V této věci je velmi důležité podtrhnout, že používání prvků a pojmových nástrojů vycházejících z filosofie anebo z jiných vědních oborů v rámci teologie vyžaduje rozlišování, které má své poslední měřítko ve zjevené nauce. Je to zjevená nauka, která má poskytovat kritéria pro rozlišování těchto prvků a pojmových nástrojů, a nikoli naopak." KONGREGACE PRO NAUKU VÍRY. Donum veritatis - o církevním povoláni teologa, instrukce ze dne 24. 5. 1990, čl. 10; český překlad Štěpán M. Filip, Olomouc: MCM, 1999, s. 12. 
Jakmile se morální „teologie“ vzhledem k dogmatice „emancipuje“ natolik, že už ji vlastně nepotřebuje, přestává být teologií v pravém slova smyslu. Hrozí jí, že se stane hledáním či spíše konstruováním jakési „autonomní morálky“, která je pochopitelně v područí „čistého rozumu“, jenž se mylně považuje za poslední instanci. ${ }^{22}$ Taková morálka může na první pohled vyvolávat zdání, že je přijatelná pro všechny. V daném kontextu si ale musíme položit palčivou otázku: Lze konstruovat etiku, aniž by $\mathrm{v}$ jejím pozadí nebyla určitá specifická antropologie? Pokud tím člověkem není Kristus, definitivní zjevení Boha, ${ }^{23}$ tak kdo? Lze konstruovat etiku, aniž by určitá hodnota byla ústřední a řídící? Není-li na prvním místě Trojjediný, pak co nebo kdo? Komu nebo čemu se $\mathrm{v}$ takovém př́padě implicitně klaníme? Jenomže žádná modla není s to dávat život a svobodu, žádný idol nemůže být opravdu univerzální. Sám princip hereze totiž ř́ká, že určitá částečnost na sebe klamně bere háv plností a definitivního vysvětlení všeho. Toto mrzačení skutečnosti však nakonec musí skončit krachem, žádná ideologie nemá šanci na pravou univerzalitu. Dějiny o tom vydávají zcela jasné svědectví.

Výmluvným př́kladem ožehavosti pomèru mezi mystériem víry a etikou je problematika vyhraněných forem teologie osvobození. Opomíjení transcendentní a mysteriózní spásy podle Boha a redukce soteriologie na spásu podle člověka nakonec vede nejen $\mathrm{k}$ imanentizaci, ale také $\mathrm{k}$ ideologizaci tajemství víry, což ale rozhodně nemůže dlouhodobě obstát v lučavce času, byt' by podobné teze $\mathbf{v}$ daném momentě působily sebelíbivěji. Řečeno jinak: dogmatická teologie by zde byla pohlcena určitou imanentisticky pojímanou formou morálky či sociální etiky, která by byla podobně jako revoluce $\mathbf{v}$ komunistické ideologii povýšena na absolutní hodnotu, tedy v zásadě „zbožštěna““.24 $\mathrm{Na}$ druhou stranu důsledné opomíjení spásy podle člověka by zase znamenalo uzavírání se dogmatiky do své

22 Srov. TREMBLAY, Réal. Cristo e la morale in alcuni documenti del magistero. 1. vydání. Roma: Edizioni Dehoniane, 1996, s. 114. Jako hlavní představitel této nezávislé morálky je uváděn Alfons Auer (zemřel 21. 11. 2005) a jeho kniha Autonome Moral und christlicher Glaube. 1. vydání. Düsseldorf: Patmos-Verl., 1971, 2., upravené vydání. Düsseldorf: Patmos-Verl., 1984.

23 Srov. Gaudium et Spes, čl. 22 (český překlad Dokumenty II. vatikánského koncilu. 1. vydání. Praha: Zvon, 1995, s. 199).

24 Srov. TORZINI, Roberto. Marx Karl - Marxismo. In BONI, Lamberto (ed.). Enciclopedia Garzanti di Filosofia. Milano: Garzanti edit., 1981, s. 565-569; BLECHA, Ivan. Marxismus - Marxismus-leninismus. In Filosofický slovnik. Olomouc: FIN, 1995, s. 261-262. Jednou ze základních tezí marxismu, zejména pak marxismu-leninismu, je dominance praxe nad teorií, ba pohlcení teorie praxí. To vede nevyhnutelně k instrumentalizaci pojmu pravdy, jíž je to, co momentálně prakticky slouží „partaji“. V hodinách politické výchovy jsme tisíckrát slýchali: „Filosofové se snažili svět vysvětlit, svět je ale třeba změnit.“ Otázkou ale je, jak máme svět proměňovat, když ho 
vlastní teoretické sféry a odvracení se od praktické oblasti. Právě vyváženost obou komponentů, tedy spásy podle Boha a spásy podle člověka, jak to vidíme v knize Exodus a v dalších knihách Mojžíšových ${ }^{25}$ nebo ve dvou fázích Ježíšova veřejného působení, ${ }^{26} \mathrm{v}$ sobě tají paradigma zdravého poměru mezi dogmatickou a morální teologií. ${ }^{27}$

Je vcelku jasné, že teologie musí být „imanentní“ dnešnímu světu, být na úrovni současné vědeckosti, zároveň ale musí být vzhledem k dnešnímu světu transcendentní jako je Ten, o němž se teologie snaží vypovídat. Zvěst o pravé svobodě a osvobození se musí nechat oslovovat současností, prostupovat radostmi a bolestmi současných lidí, zároveň ale musí zůstat $\mathbf{v}$ pravém slova smyslu vůči tomu všemu také svobodná. Jsme sice ve světě, avšak nesmíme být ze světa (srov. Jan 18,36). Jak tento paradox imanence a transcendence, vědeckosti a věrnosti zjevení realizovat, tot́ ne právě snadná otázka. Základní principy jsou zřejmé, nicméně jejich konkrétní aplikace před námi leží jako výzva.

Mělo by být všeobecně známo, že jakási „čirá přirozenost“, která by představovala ideální společný styčný bod mezi empirickými údaji vědy o člověku na jedné straně a požadavky nadpřirozeného zjevení na straně druhé, zkrátka a dobře neexistuje. ${ }^{28}$ Je známo, že hledání takové přiroze-

dobře nechápeme. Výsledek tohoto opomíjení pravdy a teorie je jednoznačná deformace reality, následné utrpení miliónů lidských bytostí a rozvrácený svět. Ti křestané, kteří hlásají absolutizaci praxe a stavějí se zády k dogmatické teologii, si zřejmě plně neuvědomují, že vlastně kráčejí ve šlépějích Karla Marxe, Bedřicha Engelse, Vladimíra Iljiče Lenina a dalších.

Vyvedení z Egypta = spása podle Boha. Čtyřicet let putování po poušti před vstupem do země = spása podle člověka.

26 První fáze, tj. hlásání Božího království, zástupy, uzdravování = spása podle člověka. Druhá fáze, kdy Ježíš vědomě putuje do Jeruzaléma, aby zde položil život „za mnohé“ (srov. Mk 10,45) = spása podle Boha.

27 Srov. POSPÍŠIL, Ctirad V. Ježíš z Nazareta, Pán a Spasitel. 3. vydání. Kostelní Vydří - Praha: Karmelitánské nakladatelství - Krystal O.P., 2006, s. 189-293.

28 To mimo jiné vyplývá také ze skutečnosti, že Boží zjevení nám nedává žádnou indikaci ohledně existence nějakého čistě přirozeného posledního cíle lidské bytosti. Onou „čistě přirozenou“ verzí spásy, jakousi „blažeností“ bez patření na Trojjediného, by podle některých teologů z minulých staletí měl být tak zvaný limbus puerorum, kde by věčně pobývaly děti, které zemřely nepokřtěné a byly zatíženy pouze dědičným postižením, poškozením (tímto výrazem se pokouším nahradit ne právě štastnou terminologii „dědičná vina“ - srov. POSPÍŠIL, Ctirad V. K problematice tak zvané „nové teologie dědičného hříchu“. Studia Theologica 2009, roč. 11, č. 1 (35), s. 80-88). Vzhledem k tomu, že zjevení nás k podobným úvahám neopravňuje, se dnes absolutní kvalifikovaná většina teologů kloní k mínění, že nauku o limbu je třeba vnímat jako cosi historicky překonaného. Srov. MEZINÁRODNí TEOLOGICKÁ KOMISE. Nadèje na spásu pro déti, které umiraji nepokřtèné. 1. vydání. Praha: Krystal O.P., 2008. Z toho ale nevyhnutelně vyplývá v zásadě jednoznačné odmítnutí „čiré přirozenosti“. 
né báze jako společného jmenovatele se objevuje na počátku novověku v souvislosti s konfesním rozpadem původně jednotné křestanské západní a střední Evropy. Ve stejném dějinném kontextu se také postupně začal rodit dnes již opuštěný koncept přirozeného náboženství. ${ }^{29}$ Následně se hledání společné báze přirozenosti akcentovalo $\mathrm{v}$ souvislosti s narůstajícím monologickým antropocentrismem, který se chtěl ve jménu humanity důsledně „emancipovat“ z područí mystéria, dogmatu a církve. ${ }^{30}$ Vrcholem naivní „víry“ $\mathrm{v}$ jakousi „čistou přirozenost“ bylo přesvědčení komunistů, že stačí změnit sociální poměry, a tak budou odstraněny problémy kriminality a náboženství, které byly z hlediska výstavby nového světa i v totalitní právní praxi stavěny na podobnou rovinu. Dvacáté století však zcela jasně dokládá, že monologický antropocentrismus je v posledním důsledku velmi nelidský. Žádná čistá nebo čirá lidská přirozenost prostě a jednoduše neexistuje.

Na zjevení stojící křestanská víra nás učí, že lidská přirozenost má v sobě zakódováno směřování k nadpřirozenému cíli, jehož však pouze svými vlastními silami nemůže dosáhnout. Ztratí-li uschopnění odpovídající tomuto cílovému zaměření, tedy milost, pak nevyhnutelně upadá do rozporu sama se sebou. Přirozenost bez milosti posvěcující je nevyhnutelně pokřivená (cor curvatum in se). Klasická teologie ji označuje jako „natura lapsa“, a když o něčem vypovídá, že je to přirozené, pak se tím nemíní to, co v nynějším stavu „dělají skoro všichni“, nýbrž lidství napravené v Kristu díky daru Ducha svatého. Je evidentní, že porozumění takovémuto pojetí přirozenosti nevyhnutelně předpokládá otevřenost transcendenci, což je však základní forma obrácení. Kde takovýto postoj schází, tam je dialog mezi vědou a vírou pro reprezentanty světa velmi obtížný, někdy téměř nemožný.

29 Vladimír Boublík jako průkopník na poli teologie mimokřestanských náboženství na počátku sedmdesátých let minulého století sice odmítal koncept báze jakéhosi přirozeného náboženství, zároveň ale hovořil o jakési všelidské náboženské zkušenosti. Srov. BOUBLÍK, Vladimír. Teologie mimokřestanských náboženství. 1. vydání. Kostelní Vydří: Karmelitánské nakladatelství, 2000, s. 69nn.

30 „Osvícenská polemika se ovšem nevyčerpávala šarvátkami v jednotlivých dílčích a celkem okrajových oblastech [...]. A tu bylo nekompromisně odmítáno především učení o dědičném hříchu. [...] Snad žádné jiné údobí nevěnovalo problému theodicey tolik pozornosti jako právě osvícenství. Přitom však základní osvícenský postoj naznačuje, že tu nešlo tak o ospravedlnění Boha, jako spíš o průkaz dobroty přirozenosti vủbec a lidské zvlášt'. Posledním motivem tohoto myšlenkového pochodu nebyla theodicea, ale skrze ni anthropodicea." LOCHMAN, Jan Milíč. Náboženské myšleni českého obrození: kořeny a počátky. 1. vydání. Praha: Komenského evangelická fakulta bohoslovecká, 1952, s. 48-49. 
Na druhé straně ale platí, že teologie navzdory nesnázím dialogu s vědami, které stavějí na empirii a na tom, co dělá většina lidí, skutečné přínosy takovéhoto vědeckého poznání zohledňovat nejen může, ale dokonce $\mathbf{v}$ jistém slova smyslu někdy také musí. Vědy totiž mají svou samostatnost, kterou musíme respektovat. Vedle knihy zjevení (Bible) existuje nepopiratelně také „kniha stvořeni““.31 Předchozí generace toho o člověku a dějinách rozhodně nevěděly tolik jako my. Nejen morální teologie, ale i dogmatika proto nesmějí zůstat k přínosům moderní vědy o člověku hluché.

Jako př́klad lze uvést přínosy paleoantropologie $\mathrm{v}$ otázce vzniku člověka. Teologie, která přijímá fakta nalezených kosterních ostatků předků dnešního člověka a nástrojů pravěkých forem člověka, bude zásadně odmítat jejich imanentistickou a materialistickou interpretaci. ${ }^{32}$ Teologové si v dané souvislosti ale mnohem zřetelněji nežli dříve uvědomují, že člověk je opravdu tělesnou bytostí, která je spjata s živočišným světem této planety, a proto není možné dělat $\mathrm{z}$ něho v přeneseném slova smyslu násilím „anděla“. Zároveň ale nikdy nesmíme přijmout to, že člověk by byl jenom určitým druhem zvířete. ${ }^{33} \mathrm{Na}$ tomto místě je třeba připomenout, že pod vlivem tvrdých údajů přírodních věd došlo k jasnějšímu vymezení kompetenčního pole neomylnosti biblických textů, což zase vedlo k prohloubení vědomí ohledně rozličnosti literárních druhů v Bibli a o jejich vlastní vypovídací hodnotě.

Principy, byt' mají paradoxální povahu, jsou poměrně snadno proklamovatelné, jejich konkrétní aplikace však nevyhnutelně plní naše čela vráskami. Do hry tu jednoznačně musí vstupovat nejen náš um, ale také tvůrčí působení Ducha svatého, jenž je dárcem osvobozující pravdy. Každopádně platí, že teologie jako taková má povahu mediace mezi zjevením na jedné straně a současnou dobou, kulturou, filosofií, přírodními a antropologickými vědami na straně druhé. Jednoznačným pochybením by byla jak ztráta transcendence tak imanence vủči dobové vědě a kultuře. A nejde jenom o to, abychom byli „na výši doby“, nýbrž také o to, abychom začleňováním všeho, co je na soudobém vědeckém

31 Výraz užíval již Bonaventura z Bagnoregia a kupříkladu také Galileo Galilei.

32 Srov. např. MEZINÁRODNÍ TEOLOGICKÁ KOMISE. Společenství a služba, čl. 62-70.

33 Těm, kdo tak rádi „vzdychají“ nad zpozdilostí teologie v otázce stvoření - vývoje člověka, si dovolím připomenout publikaci: AUGUSTIN, Bedřich. Základní náboženská nauka - apologetika. 2. vydání. Praha, 1946, 1. vydání 1939, kde je velmi dobře prezentována dobová koncepce vzniku člověka podle paleoantropologie a kde se zároveň tvrdí, že křestan to vše smí přijímat za předpokladu, že rozlišuje lidskou duši od zvířecí. Srov. POSPÍŠIL, Ctirad V. Teologie a paleoantropologie. Teologické texty 2006 , roč. 17 , č. 3, s. 162-163. 
poznání knihy stvoření pravdivé, do teologie předkládali zmíněné úctyhodné výdobytky lidského snažení našemu Pánu k povznesení, posvěcení a proměnění obdobně jako obětní dary při mši svaté.

\section{Morální teologie z hlediska soteriologie ${ }^{34}$ a christologie}

V souvislosti s tématem této studie určitě není bez významu, že Bible je neomylná v tom, co se týká naší spásy. ${ }^{35}$ Jestliže Dei verbum nepoužívá okřídlený výraz „víra a mravy“, má to své hluboké opodstatnění jednak v tom, že „víra“ vykazuje nejenom teoretický rozměr a „mravy“ nejsou pouhou praxí bez reflexe a určité teorie. Zkrátka a dobře, ve Zjevení se nám nabízí prapůvodní jednota obou aspektů, jejichž společným jmenovatelem je spása. Lze tedy říci, že problematika poměru mezi dogmatickou teologií a morální teologií bude ležet, mimo jiné, také na poli soteriologie, která je nevyhnutelně úzce spjata s christologií. Výše jsme se zmínili o tom, že pomèr mezi spásou podle Boha a spásou podle člověka má v mnoha ohledech analogické rozměry jako poměr mezi dogmatickou a morální teologií. Nyní se zamyslíme nad zřejmě nejstarší ze všech kontroverzí křestanské teologie, v níž se jednalo o to, co je posledním důvodem a měřítkem našeho ospravedlnění před Bohem.

Konkrétně jde o otázku, zda se mají „pohanokřestané“ nechat obřezat. Naplno se projevuje v listu Galatanům ${ }^{36}$ a následně také v listu Římanům, kde Pavel dokládá, že naše ospravedlnění nastává díky víře v Ježíše Krista, a nikoli na základě zachovávání skutků mojžíšovského zákona. Ve hře pochopitelně nebyla pouze otázka praktické disciplíny, nýbrž především to, jaký statut vlastně náleží Ježíši Kristu. Pro mnohé židokřestany bylo velmi obtížné přijmout, že Ježíš je víc než Mojží̌šuv zákon, protože Tóra byla v zásadě výrazem židovské národní identity. Přijmout Ježíšovo božství proto znamenalo vyjít z vlastního národního a náboženského partikularismu, což je pochopitelně velmi svízelné, a proto mnozí židokřestané přijímali Ježíše pouze jako proroka, který byl pod Mojžíšovým záko-

34 Na tomto místě si dovolím upozornit na: VERDES, Alvarez Lorenzo - MAJORANO Sabatino (ed.). Morale e redenzione. 1. vydání. Roma: Ed. Academiae Alphonsianae, 1983; ANCONA, Giovanni (ed.). La giustificazione. 1. vydání. Padova: ATI - Messaggero, 1997; GALVÁN, José María (ed.). La giustificazione in Cristo: Atti del II Simposio Internazionale della Facolta di Teologia - Roma 14-15 marzo 1996. 1. vydání. Citta del Vaticano: Libreria editrice vaticana, 1997. Srov. Dei verbum, čl. 11 (český překlad Dokumenty II. vatikánského koncilu, s. 115). List je dnes datován někdy kolem roku 56, ale není vyloučeno ani dřívější sepsání. Jedná se tedy o redakčně jeden z nejstarších novozákonních spisů. Srov. TICHÝ, Ladislav. Úvod do Nového zákona. 1. vydání. Svitavy: Trinitas, 2003, s. 190. 
nem. Základním zprostředkováním mezi námi a Bohem by pak zůstala Tóra a Ježíš by byl pouze jejím vykladačem, pročež by bylo za účelem dosažení spásy nutné přijmout obřízku. Proti tomu se ale Pavel staví velmi razantně: spasitelem ve vlastním smyslu není Mojžíšův zákon, nýbrž Ježíš Kristus. Z uvedeného důvodu ospravedlnění nedocházíme zachováváním skutků zákona, nýbrž vírou v Ježíše Krista. Je-li je však Ježíš Kristus víc než zákon, pak mu nevyhnutelně př́sluší božský statut, protože nad zákonem je jedině Hospodin. Kontroverze ohledně obřízky byla tudíž sporem o to, zda Ježíš Kristus je nad nebo pod zákonem, sporem o jeho božství, což je ustavující kritérium křestanské identity.

V této souvislosti si dovolím podotknout, že daná otázka je v jistém slova smyslu neuralgická dodnes. ${ }^{37}$ Může totiž velmi snadno dojít $\mathrm{k}$ tomu, že místo Mojžíšova zákona dosadíme náš vlastní seznam předpisů, př́kazů a zákazů, který je vypracován nejen na základě materiálu obsaženého v Bibli, ale třeba také za výrazné pomoci stoické či jiné filosofie. Nyní se ale opět objevuje otázka: Spásu nám zajištuje dodržování těchto předpisů a zákazů, anebo Kristus? Odpověd' je jednoznačná, nebot před skutky má prioritu milost a osobní vztah k Otci v Synu a Duchu svatém, jak to konec konců ř́ká Pavel v Gal 4,4-7. Novým zákonem, novou Tórou je přece sám Kristus. Konec konců Ježíšův postoj k Mojžíšovu zákonu jednoznačně ukazuje na jeho svobodu, autoritu, nadřazenost, on je víc než tyto předpisy, on je naplněním zákona (srov. Mt 5,17). ${ }^{38}$ Morální zákon je užitečná a potřebná věc, nicméně není to realita sama v sobě absolutní. Z křestanského hlediska musíme říci, že tento souhrn předpisů a zákazů nás přivádí ke spáse jedině natolik, nakolik nás spodobuje s Kristem a skrze něho s Bohem. ${ }^{39}$ Jestliže tedy Pavel staví Ježíše Krista nad Mojžíšův zákon, a to ve jménu naší svobody a dospělosti Božích synů a dcer v Kristu a v Duchu,

37 Snad je na tomto místě vhodné připomenout, že list Galatanům byl ve velké oblibě u reformátora M. Luthera. Srov. CARREZ Mario. Paolo e le chiese di Galazia. In GEORGE, Augustin - GRELOT, Pierre (ed.). Introduzione al Nuovo testamento. Sv. 3. Le lettere apostoliche. 1. vydání. Roma 1989, s. 97-110, zde s. 108-110. Je pochopitelné, že s otázkou interpretace tohoto listu a tematicky s ním velmi úzce spjatého listu Římanům souvisí „dogmatická“ otázka ospravedlnění, o níž se vedly spory mezi katolíky a evangelíky. V posledních letech se ale objevují náznaky, že dané názorové rozdíly ve skutečnosti nejsou tak diametrálně odlišné. Srov. Společná deklarace katolické církve a Luterského světového svazu k učeni o ospravedlnèni z roku 1997, český překlad se nachází v publikaci: MACHULA, Tomáš (ed.). Ospravedlněni a hřch v ekumenickém dialogu. 1. vydání. Praha: Krystal O.P., 2000, s. 5-24.

Srov. BENEDIKT XVI. Ježís Nazaretský. 1. vydání. Praha: Barrister \& Principal, 2007, s. $88 \mathrm{nn}$.

39 Srov. např. TREMBLAY, Réal. Cristo e la morale in alcuni documenti del magistero; GOFFI, Tullo. Etica cristiana trinitaria. 1. vydání. Bologna: EDB, 1995. 
pak to evidentně odpovídá tomu, jak se v době svého pozemského putování prezentoval sám Muž z Nazareta, když prokazoval, že Syn člověka má moc odpouštět hříchy (srov. Mk 2,1-12), když vykládal zákon jako ten, kdo má moc (srov. např. Mk 1,22), když prezentoval svou autentickou interpretaci zákona jako jeho naplnění (srov. např. Mt 5,17.21-22;27-28...). V dané souvislosti určitě není bez významu, že Ježíš vždy hovoří sám za sebe, a nikdy nepoužívá formule proroků, kteří sdělovali, že se k nim „stalo Boží slovo“. 40

Jistě by bylo špatné, kdybychom morálku démonizovali a stavěli do protikladu s Kristem, nicméně jedním dechem je nutno dodat, že morálku nesmíme nadřazovat Kristu, a tak redukovat křestanství na legalistické moralizování, jímž se přece vyznačovali Ježíšovi odpůrci v evangeliích.

Sám Pavel Mojžíšův zákon hodnotil pozitivně jako vychovatele v době naší nedospělosti, jakmile však nastoupí dospělost zjevené víry, pak zákon se svými předpisy ustupuje do pozadí (srov. Gal 3,23-29). Zároveň je ale třeba podotknout, že mezi jednotlivými názorovými orientacemi v židokřestanství prvních desetiletí po Velikonocích byly poměrně značné rozdíly. Víme kupříkladu, že představený křestanské obce v Jeruzalémě po Petrovi, tedy Jakub, velmi důsledně zachovával všechny židovské předpisy. To mu ale nebránilo $\mathrm{v}$ přátelských vztazích $\mathrm{k}$ církvím, $\mathrm{v}$ nichž byli přijímáni pohano-křestané bez toho, že by byli obřezáváni. Ukazuje se tedy, že samo zachovávání Mojžíšova zákona ještě nemuselo znamenat jasné odmítání Ježíšova božského statutu. Jakub byl ale navzdory své věrnosti Tóře v roce 62 ukamenován. Militantní judaisté se stavěli velmi ostře proti novému náboženství. ${ }^{41} \mathrm{Z}$ řečeného vyplývá, že by mohla existovat specifická partikulární židokřestanská církev, která by vyznávala Ježíše jako Syna Božího a která by zároveň zachovávala určité předpisy Mojžíšova zákona jakožto znamení specifické identity vyvoleného národa i v rámci světové církve. $V$ tomto smyslu je srozumitelné, když Pavel chtěl, aby se etnický Žid Timotej nechal i jako křestan obřezat (srov. Sk 16,1-5), zatímco u Nežida Tita obřízka nepřipadala do úvahy. ${ }^{42} \mathrm{~S}$ řečeným by mohlo souviset i to, že se Pavel v Jeruzalémě na popud představených jeruzalémské obce odhodlal podstoupit obřady nazirejského zasvěcení v jeruzalémském chrámu (srov. Sk 21,17-26). Zákon, předpi-

40 Srov. SKALICKÝ, Karel. Ježí̌̌ z Nazareta - otázka a výzva človéku naši doby. 1. vydání. České Budějovice: TF JČU, 2008, s. 13.

41 Srov. CARREZ, Mario. Paolo e le chiese di Galazia, s. 97-110, zde 103-104.

42 Srov. HOLZNER, Josef. Apoštol Pavel. 1. vydání. Praha: L. Kuncíř, 1939, s. 197. 
sy, morálka jsou tedy pozitivní, pokud je vnímáme jako cestu ke Kristu. Jakmile bychom je však nadřazovali Kristu, je to scestné, protože se tím soubor předpisů idolatricky nadřazuje živému Bohu a Kristu.

Na tomto místě je nutné upozornit, že podobné tendence oddělovat zákon a morálku od Krista a nadřazovat je Kristu se objevují neustále. Musíme je hodnotit jako pokušení, protože se jedná přinejmenším o implicitní popírání víry v Ježíše jako Božího Syna, což nevyhnutelně implikuje negaci Nejsvětější Trojice. Pak není divu, že kantovská redukce „teologie“ na etiku, či spíše funkcionalizace náboženství ve smyslu etiky, kterážto tendence se tak často projevovala a bohužel někdy ještě i dnes projevuje v redukci kázání na moralizování, je předposledním krokem na cestě $\mathrm{k}$ modernímu ateismu. ${ }^{43} \mathrm{~V}$ tomto kontextu se zdá být vhodné př̀pomenout Dostojevského román Idiot, který v zásadě představuje ostrou kritiku praktikování „evangelijní“ morálky bez Krista. ${ }^{44}$ Redukce Krista na učitele jakési vyšší morálky, která implikuje podřazení Mistra zvěsti a nauce, sice neznamená nadřazování starozákonní Tóry Kristu, ve skutečnosti je to ale strukturálně totéž, protože spasitelem zde není osoba Ježíše z Nazareta, nýbrž pouze soubor předpisů, tedy jakási mravní nauka oddělená od jeho osoby. Určitě není náhodou, že pro nekřestanské myslitele, kteří hovoří o Ježíšovi, je téměř vždy dominantní Ježíšova předvelikonoční etická zvěst, ${ }^{45}$ přičemž tajemství kř́iže a vzkříšení stejně jako osoba našeho Mistra pro ně nebudou víc než okrajovou záležitostí. ${ }^{46}$

43 Srov. POSPÍŠIL, Ctirad V. Trojjediné proč. In ČERNUŠKA, Pavel - POSPÍŠIL, Ctirad V. (ed.) Vydávat počet ze své nadéje: sbornik $k$ 60. narozeninám Mons. Jana Graubnera, Velkého kanclére CMTF UP v Olomouci. 1. vydání. Olomouc: UP v Olomouci, 2008, s. 52-73.

44 „Dostojevského román Idiot můžeme vnímat jako reakci na tento falešný idealismus. Setkáváme se zde s knížetem, který se objevuje $\mathrm{v}$ bohaté petrohradské společnosti jako viditelné vtělení evangelia: nikoho neposuzuje, není chtivý peněz, nikdy se neuráží [...]. Nikdy se ale nemodlí a také nehovoří o Kristu. Zpočátku na něj lidé pohlížejí s obdivem. Na konci ale vzbuzuje nespokojenost, způsobuje zmatky a romanopisec jej nechává skončit v blázinci. Dostojevského myšlení je jasné: praktikovat evangelijní pokoru a nemít při tom v sobě Krista je naprosté šílenství. Z uvedeného důvodu nemůže být zajedno s Tolstojem, který hledá Kristovo blahoslavenství mimo Krista. Je totiž dobře známo, že pro Tolstoje byla osoba Spasitele čímsi mytologickým, a proto oceňoval v evangeliu se nacházející obecně platné ideje." ŠPIDLÍK. Tomáš. Věrím $v$ život věčný: eschatologie. 1. vydání. Olomouc: Refugium, 2007, s. 218.

45 Srov. AMATO, Angelo. Gesù il Signore: Saggio di Cristologia. 1. vydání. Bologna: Ed. Dehoniane, 1998, s. 14; AMATO, Angelo. Gesù di Nazaret nel dialogo dei cristiani con le religioni mondiali e la cultura laica. In IAMMARONE, Giovanni (ed.). Gesù Cristo, verità di Dio e la ricerca dell'uomo. 1. vydání. Roma: Herder, 1997, s. 431-466.

46 Ne zcela případně se v tomto případě hovoří o „christologii zvenku“. Srov. POSPÍŠIL, Ctirad V. Ježíš z Nazareta, Pán a Spasitel, s. 24-25. 
Možná to pro někoho bude překvapující, ale onomu nadřazování Tóry Ježíšovi se strukturálně podobá i vyhraněný „Kingdom-centrism“, který by ze středu našeho zvěstování chtěl na jedné straně odstranit osobu Ježíše Krista a velikonoční drama a na druhé straně učinit středem hlásání Boží království pojímané jako ustavení spravedlivé společnosti na této zemi. ${ }^{47}$ To je ale stejně pošetilé, jako chtít hrát Hamleta bez posledního obrazu; jako vyprávět anekdotu bez pointy; jako proměnit Boží království z eschatologického daru na pouhý výkon ze strany člověka. Identifikace Krista s Božím královstvím se stává zřejmou právě ve Velikonočním dramatu, v němž se definitivně zjevuje identita Krále - Pomazaného - Krista, vlastní povaha jeho kristovství - mesiášství, a proto také pravá identita Božího království jako takového. Právě na tomto základě pak církev, pokračujíc v Mistrově poslání, navázala na jeho zvěst o Nebeském království hlásáním eschatologického Krále celého kosmu a všech věkủ, Ježíše jako Krista. Výraz „Boží královstvi“" bez křiže a vzkř́íšení je totiž významově zamlžený, a proto také „vhodný“ k nejrozličnějším ideologickým manipulacím. ${ }^{48}$

Vrat́me se ale k Pavlovi, jehož učení ohledně podřízené role zákona vzhledem ke Kristu určitě nesmíme vykládat tak, jako kdyby se mělo jednat o ospravedlňování nemorálnosti. Právě naopak totiž platí, že spravedlnost vyplývající z křestanova zakořenění v Kristu má vyšší kvalitu než spravedlnost, která staví na legalistickém plnění neosobních norem (srov. např. Řím 6,1-11). Jestliže $\mathbf{v}$ případě „morálky předpisů“ člověk klade otázku, kam je ještě možno jít, aby se nejednalo o porušení zákona, pak v morálce osobního vztahu lásky k Pánu a k bratřím si milující klade spíše otázku, co ještě bych mohl vykonat. Morálka je sice druhá v pořadí, protože v Písmu jasně závisí na Božím sebedarování, na tajemství vtělení, na daru Ducha (srov. Gal 4,4-7), jenž je v zásadě zákonem lásky vepsaným do srdce věřícího, není však rozhodně vůbec druhotná. Ono totiž docela obyčejné lidské soužití bez dodržování mravních principů není dost dobře možné, což si dogmatik velmi jasně uvědomí v okamžiku, když mu někdo ukradne peněženku.

\section{Morálka a Bůh či „bůh“}

Jestliže přirozené lidské soužití nutně vyžaduje mravnost, bez níž dochází k jeho destrukci, pak je zcela evidentní, že musí existovat určitá přirozená morálka či etika. Vedle toho ale existuje také morálka či etika

47 Srov. POSPÍŠIL, Ctirad V. Ježiśs z Nazareta, Pán a Spasitel, s. 320-323.

48 Srov. BENEDIKT XVI. Ježíš Nazaretský, s. 45-55. 
zjevená, jak o tom vypovídá chronologicky poslední dokument Papežské biblické komise věnovaný problematice morálky v Písmu svatém.

„Kvůli věrnosti základnímu směřování Písma svatého jako celku uvedeme na scénu možná prozatím ne zcela obvyklý pojem zjevené morálky. ... Morálce, aniž by byla čímsi druhotným, přísluší druhé místo, nebot první a ustavující je Boží iniciativa, kterou teologicky vzato zakoušíme ve formě daru ... v Bibli platí, že morálka vstupuje na scénu po zkušenosti s Bohem, přesněji řečeno poté, co Bůh se dává člověku zakusit prostřednictvím čistě milostivého obdarování.“49

Mělo by být evidentní, že souhrn morálních předpisů má jako společného jmenovatele určitou koncepci člověka, respektive spravedlivého člověka. Uvážíme-li zároveň skutečnost, že člověk je podle přesvědčení biblických autorů stvořen k obrazu a podobě živého Boha (srov. Gn 1,26), pak nezbývá než uzavřít, že obraz Boha - obraz člověka - morálka spolu nevyhnutelně souvisejí. Jaký Bůh, taková koncepce lidství a taková morálka. Zářný příklad propojení znalosti zákona a poznání Boha se vyskytuje ve slavném výroku proroka Jeremiáše 31,31-34. Jelikož toto poznání Boha není výsledkem lidského snažení, nýbrž přesně naopak výrazem Božího svobodného sklonění se k člověku, pak dar zjeveného zákona zjevené morálky je třeba vnímat $\mathrm{v}$ souvislosti s tajemstvím smlouvy. ${ }^{50}$

Tato smlouva jakožto meziosobní vztahovost Jahveho „navenek“ kvůli jeho svatosti, transcendenci, nutně odkazuje na věčnou meziosobní vztahovost - na věčnou smlouvu v božství, tedy na vztahy otcovství a synovství v imanentní Trojici. ${ }^{51}$ Proto také ten, kdo je skutečně spravedlivý před Hospodinem, je v zásadě v Synu, i když si to ve starozákonní epoše věřící člověk nemohl plně uvědomovat. ${ }^{52} \mathrm{~K}$ řečenému je třeba doplnit, že dar zákona vtištěného do srdce věřících byl již ve starozákonní době vnímán jako obdarování Hospodinovým duchem, což pak nachází definitivní výraz v seslání Ducha svatého o Letnicích. ${ }^{53} \mathrm{Z}$ řečeného plyne, že od prvopočátku biblického zjevení se člověku daruje Trojjediný, nicméně plnost zjevení tohoto mystéria nastává až v Novém zákoně spolu s vtělením Slova a plným darováním Ducha svatého. Intenzitě poznání Boha

49 Srov. PONTIFICIA COMMISSIONE BIBLICA. Bibbia e morale, čl. 4.

50 „Toto je smlouva, kterou uzavřu s domem izraelským po oněch dnech, je výrok Hospodinův: Svůj zákon jim dám do nitra, vepíši jim jej do srdce. Budu jejich Bohem a oni budou mým lidem" (Jer 31,33).

51 Srov. POSPÍŠIL, Ctirad V. Jako v nebi, tak i na zemi, s. 21-46.

52 Nikoli náhodou se spravedlivý může chlubit, že Bůh je jeho otec - srov. Mdr. 2,16.

53 Srov. POSPÍŠIL, Ctirad V. Dar Otce i Syna: základy systematické pneumatologie. 1. vydání. Olomouc: MCM, 1999, s. 61-68. 
pak odpovídá také úroveň poznané spravedlnosti, úroveň vnímání zjevené morálky, což se zcela evidentně projevuje v Ježíšově Horské řeči, kde se dozvídáme, že Ježíš nepřišel zákon (tedy starozákonní zjevení) zrušit, nýbrž naplnit (srov. Mt 5,17). Toto naplnění jde pochopitelně ruku v ruce se zjevením pravého obrazu Boha Otce (srov. Mt 11,27). Smysl zákona a celého zjevení pak tkví v tom, že máme být dokonalí, jako je dokonalý náš nebeský Otec (srov. Mt 5,48). Je-li tedy pro Syna tou nejvyšší normou sám Otec (srov. Jan 5,19), pak právě v tom také tkví poslední smysl našeho následování vtěleného Obrazu neviditelného Boha (srov. Žid 1,3; Kol 1,15). Písmo nám tudíž nenechává možnost odtrhovat mystérium Božího zjevování se a sebedarování člověku od požadavků zjevené morálky, protože když se Bůh zjevuje a jedná, je to pro nás norma zbožštění, a když nám Bůh dává svá nařízení, je to zase součást jeho sebezjevování a sebedarování. Odtrhování dogmatiky od zjevené morálky je tudíž v ostrém rozporu s poselstvím Božího slova. ${ }^{54}$

Nyní si položme otázku, $\mathrm{k}$ čemu povede odtržení etického diskursu od onoho teologického. Zůstává nevyhnutelně v platnosti, že soubor etických norem je výrazem určité koncepce člověčenství. Zároveň platí, že člověku je „bohem“ či Bohem to nebo Ten, co nebo Koho staví ve svém srdci na první místo (srov. Dt 6,4-5). ${ }^{55}$ Jakmile ale začneme konstruovat etiku bez Boha zjevení, nevyhneme se tomu, že v pozadí takovéto koncepce se začne projevovat nějaké implicitní pojetí nejvyšší hodnoty, která bude vše řídit, takže se vlastně stane „bohem“56 daného etického systému. Řečeno jinak: takzvaná přirozená etika se má ke zjevené etice obdobně nebo dokonce totožně jako takzvaná přirozená teologie k teologii vycházející z nadpřirozeného zjevení. Je tedy zřejmé, že ten, kdo se zabývá morálkou či etikou, v posledním důsledku nemá před teologickou problematikou kam uniknout. Morálka bez „boha“ či Boha neexistuje, jde jenom o to, jaký „bůh“ nebo Bůh bude explicitně nebo implicitně vzýván.

Hodnocení přirozené etiky stejně jako přirozené teologie nemůže být jednoznačné. Když se daná koncepce absolutizuje a uzavírá pravé transcendenci, stává se nikoli cestou k svrchovaně Svobodnému, nýbrž klamnou ideologií a idolatrií. Ta sice mnohé slibuje, velmi záhy však vyjde najevo, že se ve skutečnosti již od samotného počátku jednalo jen o dobře nalíčenou mumii, jejíž mrtvolný zápach nelze zakrývat věčně. Proto se

54 Srov. POSPÍŠIL, Ctirad V. Jako v nebi, tak i na zemi, s. 49.

55 Tuto myšlenku obsahuje již Velký katechismus Martina Luthera: srov. Der Grosse Katechismus Martin Luthers - „Das erste Gebot“. <hhtp://www. EKD>.

56 Nejedná se pochopitelné o Boha živého, nýbrž o „boha“ jako určitý lidský konstrukt a sebeprůmět, před čímž nás důrazně varuje Ludwig Feuerbach. 
také falešní „bohové“ a ideologie na scéně dějin tak rychle střídají. Ona přirozená etika může nabývat ateistických forem, ale také forem opírajících se o přirozený jednoosobový, tedy unitaristický monoteismus. Absolutizace této etiky a tohoto ideologického pojímání „boha“ nakonec pochopitelně představuje hrob pravé svobody. ${ }^{57}$

Jakmile je ale přirozená náboženskost člověka a takzvaná přirozená etika cestou k plnosti jménem Otec, pak je třeba tuto přirozenou teologii a etiku mít ve veliké úctě, nebot' se jedná o jednu ze základních složek naší pravé důstojnosti Božích synů a dcer. ${ }^{58} \mathrm{~V}$ tomto světle nahlíželi přínosy řecké filosofie a kultury svatý Justin a Klement Alexandrijský, když hovořili o „semenech Slova“. Naproti tomu odmítavý postoj Tertulliánův k „Athénám“ odpovídá nebezpečí zrady pohoršení evangelia a odklonu od živého Boha Otce, Syna a Ducha svatého. Ač diametrálně odlišné, přesto oba právě zmíněné postoje společně vyjadřují celou pravdu o takzvané přirozené teologii a implicitně také o takzvané přirozené etice.

Čteme-li pozorně evangelium, pak zjištujeme, že Ježíš z Nazareta bojoval právě proti ideologizaci předpisů zákona a také proti falešnému obrazu Boha či „boha“, který je s tím velmi úzce spjat. Ano, i nesprávně pochopená zjevená morálka, pokud ji absolutizujeme a učiníme z ní náhražku Svobodného, Živého a Transcendentního, se stává bariérou na cestě k plnosti, k pravému zbožštění. Tentýž Mistr ale zároveň byl zcela zřetelně a vědomě plně zajedno s autentickou vypovídací hodnotou zákona jakožto cesty, ${ }^{59}$ po níž bud' člověk kráčí v Synu a v síle Ducha svatého k Otci, anebo se od ní odkloní, a tak nakonec končí v záhubě.

Je tedy zřejmé, že Jahve není pod zákonem, nýbrž nad ním. O této nadřazenosti Hospodina mravnosti vyjádřené našimi slova a podle našich představ vypovídají některé pasáže ze Starého zákona.

$\mathrm{V}$ dané souvislosti snad postačí, když připomeneme slavné vyprávění o Abrahámově oběti Izáka. Jak je ale možné, že Hospodin chtěl po Abrahámovi zabití vlastního syna? Jak je možné, že Hospodin nařizuje něco,

57 „Tam, kde vládne velký panovník světa, zcela chybí prostor pro svobodu, a to i pro svobodu Božích dětí, stejně jako pro mysticko-demokratickou tvářnost Božího království, jak byla př́tomna v chiliastických nadějích.“ BLOCH, Ernst. Das Prinzip Hoffnung. 1. vydání. Frankfurt am Main: Suhrkamp Verlag, 1959, s. 1413.

58 Srov. např. POSPÍŠIL, Ctirad V. Ambivalence poměru mezi náboženstvím a vírou. Teologické texty 2002, roč. 13, č. 1, s. 9-10.

59 „Je tudíž jasně zřetelné, že morálka je mnohem víc než pouhá norma chování a postojů. Morálka se představuje jako zjevená a darovaná cesta (derek). Tento klíčový motiv je velmi dobře rozvinut $v$ Deuteronomiu, $u$ proroků, $v$ mudroslovné literatuře a v naučných žalmech." Srov. PONTIFICIA COMMISSIONE BIBLICA, Bibbia e morale, čl. 20. 
co je neetické? Právě tyhle otázky silně znepokojovaly velkého Sörena Kierkegaarda, který vidí jako jediné řešení nadřazenost vztahu mezi Bohem a člověkem vzhledem ke konkrétním etickým předpisům, tedy v tom, že Bůh je více než konkrétní verbalizovaná podoba přirozených a v posledním důsledku i zjevených a lidským slovem vyjádřených mravních norem. ${ }^{60}$

Jako další příklad můžeme uvést Boží příkaz adresovaný Izraelitům, kteří dobývali zaslíbenou zemi, aby vyhubili všechno původní obyvatelstvo (srov. např. Dt 33,27 ). Tento Hospodinův pokyn pochopitelně značně pohoršuje naši epochu, v níž se pozemský život stal nejvyšší, ba absolutní hodnotou. Základní vysvětlení tohoto velmi nepohodlného textu vychází z principu, podle něhož poznání Boha souvisí se sebepoznáním člověka, tedy s jeho kulturní zralostí či nezralostí. ${ }^{61}$ Příslušná výpověd' o Bohu je tedy zároveň výrazem tehdejší zralosti či nezralosti člověka, k jehož úrovni se Hospodin sklání, aby s ním komunikoval. Zároveň ale musíme jedním duchem dodat, že Hospodin není poměřován zákonem, nýbrž přesně naopak zákon Hospodinem, nebot' on je posledním měřítkem spravedlnosti, on je spravedlnost sama. Daný příkaz tedy svědčí o dobové úrovni svatopisce, o Božím sklánění se k člověku, o Boží svobodě a v posledním důsledku také o tom, že s idolatrií má člověk bojovat zcela nekompromisně, až k prolití krve, pochopitelně přednostně té vlastní, jak nás tomu učí Kristus a Nový zákon (srov. Žid 12,4).

Výpovědi přirozené i zjevené morálky tudíž vždy nějak vypovídají o Bohu či „bohu“. V př́padě, že se jedná o výroky pravdivé, musíme si být vědomi, že i zde platí princip analogie. Jestliže si je dogmatická teologie jasně vědoma provizornosti svých výpovědí o Bohu a prověřuje je stále podle paradigmatu: „krok tvrzení - krok popření - krok absolutní míry“, pak se naskýtá otázka, zda cosi obdobného by nemělo platit i o morální teologii, $\mathrm{v}$ jejímž rámci by tak klasická analogie entis a analogie víry ${ }^{62}$ nabraly formu popsatelnou jako „analogia moralitatis“. Bližší specifikace této analogie mravnosti jednoznačně překračují možnosti této práce, a proto je třeba vnímat právě předložený výsledek našeho snažení spíše jako výzvu k dal-

60 „Bud' tedy existuje paradox, že jedinec jakožto jedinec má absolutní poměr k absolutnu, anebo je Abrahám ztracen." KIERKEGAARD, Sören. Bázeň a chvéní - Nemoc k smrti. 1. vydání. Praha: Svoboda, 1993, s. 104.

61 Srov. POSPÍŠIL, Ctirad V. Jako v nebi, tak i na zemi, s. 232.

62 Problematika analogie je velmi komplexní, a proto nezbývá než odkázat na př́slušnou odbornou literaturu: POSPÍŠIL, Ctirad V. Hermeneutika mystéria, s. 106-135; PRZYWARA, Erich. Analogie entis. 1. vydání. Olomouc: Refugium, 2007; DVOŘÁK, Petr. Tomáš a Kajetán o analogii jmen. 1. vydání. Praha: Krystal OP, 2007; DVOŘÁK, Petr (ed.). Analogie ve filosofii a teologii. 1. vydání. Brno: CDK, 2007. 
šímu promýšlení a hledání. Současně je nezbytné důrazně upozornit, že nejde o relativizaci mravních principů křestanství a zdravě pojímané přirozené etiky, nebot' co do směru, jímž příslušná pravidla jako milníky na cestě spásy ukazují, jsou dané principy nereformovatelné obdobně jako dogmata. Zároveň ale platí, že stejně jako můžeme stále hlouběji a hlouběji pronikat do tajemství vyjadřovaných a zpřítomňovaných v naší pozemské realitě dogmaty víry, tak také můžeme stále hlouběji pronikat do tajemství spásy, které je spjato s výpověd'mi morální teologie. Díky analogii morality tak bude zřetelné, že i v morální teologii je velký prostor tajemství, otevřenost transcendenci, která je kořenem pravé svobody.

Vyskytuje se v Písmu svatém nějaká indikace, která by ospravedlňovala naše vypovídání o analogia moralitatis? Zdá se, že ano. Jedná se o rozlišení takzvaného apodiktického práva, které je vyslovováno ve jménu samotného Boha, a práva kasuistického. Apodiktické právo je v zásadě trvale platnou směrnicí, metanormou, na jejímž základě pak proroci a následně také sám Kristus, jak o tom vydává svědectví kupříkladu Horské kázání, kritizovali konkrétní právní zvyklosti. Apodiktické právo by tedy udávalo trvale platný směr k Bohu, sebepřekročení člověka, eschatologii, zatímco konkrétní podoby kasuistického práva by byly mimo jiné také dobově podmíněné. Platí snad pro křestany dodnes kompletně všechny starozákonní předpisy? Je jasné, že apodiktické právo má platnost trvalou, zatímco kasuistické rozhodně nikoli. ${ }^{63}$

\section{Morální teologie a mysterium Trinitatis}

Existuje-li těsná spojitost mezi morálkou a určitou koncepcí Boha či „boha“, pak před námi vyvstává otázka, jak se do oblasti morální teologie promítá tajemství Nejsvětější Trojice. Toto zamyšlení má význam nejenom pro morální teologii a její inovaci, ${ }^{64}$ nýbrž také pro trinitologii, nebot́ jedním z hlavních témat současné trojiční teologie je praktický rozměr tohoto kapitálního mystéria. Zmínka o inovaci morální teologie souvisí jednak s tím, že v minulých staletích západní teologie znala izolovaný traktát o Trojici, kde se pojednávalo především o imanentní

63 Srov. BENEDIKT XVI. Ježíš Nazaretský, s. 95.

64 Rozhodně není bez zajímavosti, že ve slovníku morální teologie nenajdeme heslo „Bůh“, natož heslo „Trojice“. Srov. COMPAGNONI, Francesco - PIANNA, Giannino - PRIVITERA, Salvator (ed.) Nuovo Dizionario di Teologia Morale. Ačkoli se jedná jen o pokus, je třeba kvitovat skutečnost, že věhlasný odborník na morální teologii a spiritualitu na sklonku svého života našel odvahu sepsat dílo s velmi odvážným titulem: GOFFI, Tullo. Etica cristiana trinitaria. 1. vydání. Bologna: EDB, 1995. Autor se bohužel nedotýká tajemství imanentní Trojice. 
Trojici, nedokázala však učinit z trinitárního mystéria základní zorný úhel, z něhož se přehlíží tajemství víry a křest́anského života. ${ }^{65}$ Není tedy divu, že v morální teologii se prozatím tajemství Nejsvětější Trojice př́liš neprojevovalo.

Nejprve je třeba připomenout, že tohoto tématu jsme se již několikrát dotkli. Velmi důležité předznamenání tématu trojiční morálky se nachází v první kapitolce tohoto pojednání, kde jsme se zmínili o perichoretickém poměru mezi dogmatikou a morálkou, což zcela evidentně souvisí s trojičním mystériem.

Další spojitost se skrývá ve výše již častokrát zmiňované Boží transcendenci vzhledem ke světu. Mělo by být jasné, že hypotetický jednoosobový „bůh“ určitého typu filosofování nikdy nemůže být opravdu svobodný - transcendentní vůči světu, nebot bezvztahovost „uvnitř“ by byla nevyhnutelně doplňována novou kvalitou vztahovosti takovéhoto „boha“ „navenek“ vůči světu a vůči lidským osobám v něm. Jedině Otec, Syn a Duch svatý mohou být skutečně nezávislí na našem světě a zároveň v něm být všudypř́tomní a nadto se svobodně darovat ve vztahu k člověku. Jedině Otec, Syn a Duch svatý jsou proto posledním zdrojem naší pravé svobody, našeho osvobození (srov. Gal 4,4-7; Mt 28,19), tajemství zjevení (srov. Jan 1,1-18), tajemství vyvolení a milosti (Ef 1,3-14).

Uvážíme-li, že božství je věčným společenstvím tří osob, pak není divu, že samo zjevení poukazuje na úzkou souvislost mezi tajemstvím Boha Otce, Syna a Ducha svatého na jedné straně a mystériem církve na straně druhé. ${ }^{6} \mathrm{~V}$ posledních desetiletích se stále intenzivněji diskutuje o křestanském sociálním učení, které - ač má výrazně interdisciplinární charakter - bývá logicky primárně zařazováno do oblasti morální teologie. A právě zde nacházíme výrazné inspirace pocházející z oblasti trinitární teologie. ${ }^{67} \mathrm{Na}$ scéně jsou tudíž velká témata: Trojiční základ nauky o lidské osobě, Trojice a uspořádání lidské společnosti, Trojice a politika. $\mathrm{V}$ daném souvislosti je zřetelné, že vláda jednoho nade všemi se snoubí s důrazem na monarchii jediné božské přirozenosti (západní teologie) či Boha Otce (východní teologie), zatímco dialogické a kolektivní formy vlády, jak je tomu kupříkladu v parlamentní demokracii, se snoubí spíše s důrazem na Trojici božských osob. ${ }^{68}$

65 Požadavek na trinitarizaci teologie a spirituality nacházíme v: Katechismus katolické církve. 2. vydání. Kostelní Vydří: Karmelitánské nakladatelství, 2001, č. 234.

66 Srov. např. Jan 17,20-23; 1 Kor 12,4-6.

67 Srov. např. PAPEŽSKÁ RADA PRO SPRAVEDLNOST A MÍR. Kompendium sociální nauky církve. 1. vydání. Kostelní Vydří: Karmelitánské nakladatelství, 2008, čl. 33-37, dále čl. 4, 27, 375, 577.

68 Srov. POSPÍŠIL, Ctirad V. Jako v nebi, tak i na zemi, s. 61-87. 
Dalším možným inspiračním prvkem pro vznik trinitární etiky je problematika „třetího, zdánlivě nepřítomného“, protože mravnost našeho počínání namnoze závisí právě na vědomí ohledně nutnosti respektovat práva tohoto „třetího“, jenž momentálně nemůže pozdvihnout svůj hlas, jelikož je na první pohled nepř́tomný. ${ }^{69}$ Láska totiž vyžaduje nejenom Milujícího a Milovaného, ale také tajemného Spolumilovaného (Condilectus), jak na to mistrovsky upozorňuje Richard od Sv. Viktora. ${ }^{70}$

$S$ řečeným souvisí také důsledněji trojiční pojetí spravedlnosti jako spodobení s vtěleným Synem, který se bezvýhradně vydává Otci a za své bratry. Etika přirozená i ta, která v našich učebnicích morální teologie ze zjevení vychází, se prozatím soustředily na hodnocení jednotlivých skutků, což rozhodně není špatně. Citelně však schází komplexnější hodnocení celého člověkova životního příběhu a jednotlivých skutků v jeho rámci. Jestliže cílem našeho pozemského putování je to, abychom se nakonec co nejdokonaleji spodobili se Synem, ${ }^{71}$ přesněji řečeno s jeho totálním sebevydáním z lásky k Otci a bratřím, pak je zřejmé, že když nastane plnost tohoto spodobení, nemá smysl hovořit o nějakém nedostatku. ${ }^{72}$ Tam, kde je plnost lásky, nemá místo hřích, který je přece primárně jejím nedostatkem nebo deformovaností. ${ }^{73}$ Neplatí snad, že láska přikrývá všechny hříchy (srov. 1 Petr 4,8)? Pokud etika ctností a jednotlivých skutků vede $\mathrm{k}$ tomuto transcendentnímu cíli, je vše $\mathrm{v}$ pořádku. Jakmile se stane etika jednotlivých skutků překážkou k realizaci tohoto vrcholného spodobení se Synem v Duchu svatém jako návrat k Otci, pak se stává z hlediska

69 Srov. POSPÍŠIL, Ctirad V. Jako v nebi, tak i na zemi, s. 383n.

70 Srov. RICHARD OD SV. VIKTORA. De Trinitate III, 14.

71 Rozhodně není bez zajímavosti, že Synu v jednom ze základních modelů rozlišování působení osob Trojice v díle stvoření a spásy, přísluší role vzorové příčiny, přičemž Otec hraje roli příčiny účinné a Duch svatý př́ičiny účelové. Srov. Ef 4,6; 1 Kor 8,6; BASIL, De Spiritu Sancto 16,38; BONAVENTURA Z BAGNOREGIA. Breviloquium, prolog 6,6 - BONAVENTURA Z BAGNOREGIA. Breviloquium: kompendium scholastické teologie. 1. vydání. Praha: Vyšehrad, 2004, s. 89; LEV XIII. Divinum illud munus: Encyklika ze dne 9. 5. 1897. 1. vydání. Praha: Krystal OP, 1997, čl. 5, s. 23. Tato funkce Syna určitě úzce souvisí s kategorií následování - napodobování a pochopitelně také s morální teologií.

72 Snad je vhodné v daném kontextu připomenout román: GREENE, Graham. Moc a sláva. 1. vydání. Praha: Svoboda, 1990. Jedná se o příběh zakládající se na skutečnosti z doby pronásledování křestanů v Mexiku. Mladý kněz, který působí v utajení a pod hrozbou trestu smrti, je postaven před rozhodnutí: jít vyzpovídat umírajícího, anebo se sám jít vyzpovídat, nebot je v těžkém hříchu. Rozhodne se ve prospěch umírajícího, je ale dopaden a zastřelen, nebot to byla nastražená léčka. Intuitivně cítíme, že skutkový hřích a spása se tu dostávají do dramatického protikladu. Je ale možno uvažovat o tom, že by se tento k oběti za druhého odhodlaný člověk minul se spasením?

73 Srov. POSPÍŠIL, Ctirad V. Jako v nebi, tak i na zemi, s. 385. 
evangelia čímsi kontraproduktivním, jako tomu bylo $\mathrm{v}$ př́padě Ježíšových odpůrců $\mathrm{v}$ evangeliích. $\mathrm{V}$ takovém případě skutečně může nastat to, co na první pohled vyznívá zcela paradoxálně, totiž že nevěstky a celníci předcházejí spravedlivé podle litery zákona na cestě do Božího království (srov. Mt 21,31).

Přijmeme-li právě popsanou spojitost mezi Božím sebedarováním, zjevením (dogmatická teologie) a mravními požadavky (morální teologie) Písma svatého, pak se $\mathrm{v}$ mnohém projasňuje poměr mezi spásou jako ničím nepodmíněným darem milosti ze strany bezvýhradně svobodného Pána a spásou, která je plodem našeho svobodného jednání. Jestliže morálka je vzhledem k Božímu sebedarování, ke zjevení, k milosti druhá, avšak nikoli druhotná, pak můžeme na základě myšlenkového odkazu Bonaventury z Bagnoregia dospět k následujícímu závěru:

„Kategorie zásluhy, která je souběhem daru milosti a lidského jednání, má zcela evidentně boholidskou, tedy ,kristickou' strukturu. Primát Božího sebedarování, které předchází jakékoli lidské jednání mající hodnotu pro věčnost, se nejplnějším způsobem projevuje a realizuje v úkonu vtělení. Tento absolutní dar, toto vpravdě bezvýhradné darování se Boha člověku, je také základem jakékoli spásonosné hodnoty lidského jednání. Vždyṫ jedině sebedarování Boha člověku dává smysl dispozičním úkonům př́ijemce takového nesmírného daru. Jelikož odměnou je $\mathbf{v}$ zásadě připodobnění člověka Bohu, zbožštění, pak nepřekvapí, že základem každého zasluhování je to, co vykonal Ježíš z Nazareta, v jehož životě a jednání se Bůh sám dokonale vyjádřil, vyslovil a daroval.“74

Boží zjevení jakožto sebedarování nakonec prostřednictvím vtělení Slova ústí do lidského jednání vtěleného Syna (poslušnost), a tak se svobodné lidské jednání stává schopným vyjádřit a unést tajemství živého Boha. Kristus jasně dokládá, že člověk je capax Dei. Boží milost nás tedy uschopňuje $\mathrm{k}$ tomu, abychom se stávali tím, čím máme být, tedy syny v Synu. To ale zároveň znamená, že správně pojímaná křestanská morálka je zároveň spiritualitou následování a napodobování Ježíše Krista. ${ }^{75}$

74 POSPÍŠIL, Ctirad V. Soteriologie a teologie krǐže Bonaventury z Bagnoregia. 1. vydání. Brno: Nakl. L. Marek, 2002, s. 79.

75 „Jestliže chce církev poskytovat službu, již od ní má svět právo požadovat a již jí Pán rovněž uložil, pak se nemůže opírat pouze o teologii stvoření [...]. Církev musí vhod i nevhod (srov. 2 Tim 4,2) připomínat, že v posledním důsledku existuje jednom jeden jediný klíč k porozumění veškeré skutečnosti, totiž ,esenciální Otec‘ (Durrwell), jehož bytí začíná i končí ve věčném úkonu plození v Lásce. Z řečeného vyplývá, že veškerá skutečnost je synovská v Synu stvořiteli a vykupiteli v Lásce, a proto se toto vše má také skrze Syna vrátit v Lásce k Otci.“ TREMBLAY, Réal. Cristo e la morale, s. 197. 
K řečenému je třeba dodat, že primát milosti vzhledem k naší odpovědi, k našim skutkům, jasně odpovídá prioritě otcovství vzhledem k synovství v tajemství Nejsvětější Trojice, proto také Syn nejprve vychází z Otce, tedy je plozen, aby pak na tento nevýslovný dar odpovídal svou vděčností (srov. Mt 11,27), oslavou Otce (srov. Jan 17,1-5), když koná to, co vidí činit Otce (srov. Jan 5,19), a konečně absolutním sebedarováním - vyjitím ze sebe - návratem k Otci (srov. Jan 16,28). To, že skutky a morálka jsou v jistém slova smyslu až druhé po sebedarování Otce a milosti, se tedy zcela evidentně snoubí s tajemstvím Nejsvětější Trojice. Jestliže dar vtělení, milosti, ospravedlnění a kontemplace Božích tajemství odpovídá přednostně kompetenci dogmatické teologie a jestliže naše odpověd', plné rozvinutí nám darovaného podílu na věčném synovství v Duchu svatém zase morální teologii, pak musí platit, že odtrhování jedné skutečnosti a disciplíny od druhé je v posledku stejně nepřijatelné, jako odtrhování synovství od otcovství v Nejsvětější Trojici.

Primát dogmatické teologie vzhledem k morální teologii je tedy zakotven v tajemství Trojice jako primát otcovství vzhledem k synovství, přičemž stejně jako mezi oběma osobami je rovnost co do božské důstojnosti, tak také oběma teologickým disciplínám prrísluší tatáž důstojnost. Stejně jako Otec by vůbec nebyl, kdyby nebyl vztažen k Synovi, tak také dogmatická teologie by nebyla sama sebou, kdyby nebyla zaměřena k morální teologii, která z ní vychází analogicky jako Syn z Otce. Stejně jako otcovství nedává smysl bez synovství a opačně, tak totéž analogicky platí o dogmatice a morálce. Zároveň se ukazuje, že zkoumání poměru mezi dogmatikou a morálkou musí vycházet z dogmatické teologie, a tak se zároveň ospravedlňuje to, co bylo řečeno v úvodu této studie, totiž že k dané otázce přistupuji z hlediska své specializace, tedy z hlediska dogmatické teologie. Pozorný čtenář těchto stránek si zřejmě již sám stačil uvědomit, že právě nastíněný trojiční model pojímání vztahu mezi oběma disciplínami také definitivně řeší problém poměru mezi Synem a zákonem či souborem morálních předpisů, jejichž soteriologická hodnota nachází své teologické ospravedlnění jedině tehdy, když odkazují na Syna (srov. Jan 5,39), když vyzařují ze Syna. Jestliže platí, že tajemství Ježíše Krista se vymyká definitivní systematizaci, ${ }^{76}$ pak také morální

76 „Jednota víry a pluralita jejích vyjádření mají svůj poslední základ v tajemství samotného Krista, které, ačkoli je tajemstvím univerzálního usmírení a obnovy, nápravy, shrnutí (srov. Ef 2,11-22), překračuje výrazové prostředky každé historické epochy, a proto se vymyká jakékoli vyčerpávající systematizaci (srov. Ef 3,8-10).“ MEZINÁRODNÍ TEOLOGICKÁ KOMISE. Jednota víry a teologický pluralismus, dokument z 11. 10. 1972, čl. 1. In POSPÍŠIL, Ctirad V. Hermeneutika mystéria, s. 164-166, zde 164 . 
předpisy vyjádřené lidskými slovy mohou o Synu jako věčném Zákonu vypovídat pouze analogicky, pročež, jak bylo řečeno výše, do hry musí vstupovat „analogia moralitatis“.

Právě nastíněný trojiční pohled na tajemství ospravedlnění a následně na poměr mezi dogmatikou a morálkou určitě není v rozporu s klasickou teologií, protože např́klad slavná Summa Theologiae Tomáše Akvinského je strukturována podle schématu exitus - reditus, přičemž témata v části věnované návratu tvora do Boha se výrazně podobají tomu, o čem hovoří morální teologie. ${ }^{77}$ Dlužno však podotknout, že výchozím a cílovým bodem tohoto klasického schématu je jediný Bůh, Trojice jako jednota ve vztahu ke stvoření. $V$ našem př́padě je výchozím a cílovým bodem Otec, návrat tvorů se uskutečňuje v Synu, s nímž nás vnitřně spodobuje Duch svatý.

Nyní jasněji vnímáme i to, jak důležité je pro dogmatickou teologii samotnou, aby správně vnímala své těsné propojení s morální teologií. Přehlížet morální teologii, podceňovat ji, usilovat o její pohlcení, by z hlediska dogmatické teologie bylo nejen nekorektní, nesmyslné, ale v posledku vlastně „sebevražedné“. Totéž ale pochopitelně platí i opačně, tedy z hlediska poměru morální teologie k teologii dogmatické. Zkrátka a dobře, odtrhování obou disciplín se přičí křestanské identitě a především trojičnímu obrazu Boha Otce, Syna a Ducha svatého.

\section{Teologie jako moudrost}

Na počátku prvního bodu této studie byla připomenuta prapůvodní harmonie mezi dogmatickou a morální teologií, k jejímuž opětnému nastolení má také toto společné usilování autora i čtenářủ pokud možno přispět. Jedním z prostředků, jak toho dosáhnout, je také schematické znázornění tajemství, díky čemuž se celá záležitost značně konkretizuje, a tak se stává mnohem snáze aplikovatelnou v životě a další reflexi. Velmi výstižné a také krásné znázornění poměru mezi dogmatikou a morálkou nacházím opět v díle Serafického doktora. Zmíněné paradigma se nyní pokusím stručně popsat.

Dlužno předznamenat, že $\mathrm{v}$ díle právě zmíněného autora moudrost znamená jednak umění zaměřovat všechno ke správnému cíli, což souvisí s bonaventurovským pojetím tak zvané „reductio“, jednak harmonické prolínání intelektu a afektu - lásky. Na počátku první knihy svého Komentáre $k$ Sentencím Petra Lombardského si Serafický učitel klade otázku, zda

77 Srov. WEISHEIPL, James A. Tommaso d'Aquino: Vita, Pensiero, Opere. 2., upravené a rozšířené vydání v italštině. Milano: Jaca Book, 1994, s. 223-225. 
teologie je přednostně milostí kontemplace (dogmatika jako nazírání Božích tajemství), anebo směřováním k tomu, abychom byli dobří (morální teologie). V odpovědi se dozvídáme, že východiskem je intelekt, který se zdokonaluje tak, že se zaměřuje trojím způsobem. Nejprve jaksi horizontálně směrem ke vznětu lásky (affectus). Následně jaksi vzhůru ke kontemplaci tajemství Božích, konečně jaksi dolů směrem k otázce, jak být správný. Teologie, které př́isluší jméno moudrost, je tohle všechno.

Pozornému čtenáři, který si vyřčené sám graficky znázorňuje, vyvstane před očima inteligibilní křriž, jehož vertikální osa probíhá mezi nazíranými tajemstvími víry a problematikou vyhrazenou morální teologii. Horizontální osa onoho kříže vychází od intelektu k afektu. Afekt je sice spjat s vůlí, ale nikoli s vůlí pojímanou jako diktátorka, nýbrž s vůlí, která je uchvácena nazíraným a zakoušeným dobrem. ${ }^{78}$ Podtrhujeme, že jedině vůle prozářená intelektem nazírajícím Boží tajemství je s to vnímat stvořená dobra jako stopu, obraz a podobu jediného Dobrého. Výhradně takto formovaná vůle je svobodná od sebe a od svého tíhnutí k tyranii. Pravá moudrost - teologie se nachází v průsečíku obou zmíněných os. Paradigma jasně naráží na ukřižovanou vtělenou Boží Moudrost. ${ }^{79}$

Síla teologie jakožto moudrosti tkví právě v její komplexnosti. Dnešní věda jde cestou stále užší specializace, což samo o sobě není špatné, pokud odborník dokáže nevyhnutelné metodologické zúžení zorného úhlu, pod nímž je v dané disciplíně nahlížena realita, nebo spíše její určitý výsek, ve svém vlastním životě překračovat. Jakmile to však odborník přestane zvládat, metodologickou restrikci zamění za existenciální restrikci, pak můžeme plným právem hovořit o „profesionální deformaci“, což je vzhledem k některým případům označení velmi eufemistické. Takový „vědec“ ví sice mnohé, nemůže ale aspirovat na to, co nazýváme moudrostí.

Máme-li před očima Bonaventurovo paradigma, pak je vcelku snadné dospět k následujícímu varování. Jestliže by se někdo chtěl věnovat výhradně „milosti kontemplace“, což by v jistém slova smyslu odpovídalo dogmatické teologii a z určitého hlediska také tomu, co nazýváme mystikou, pak by vážně riskoval, že přes veškeré své poznání nakonec upadne

78 Do hry vstupuje to, co západní spiritualita a také morální teologie ne vždy dostatečně doceňovala a doceňuje, totiž problematika tak zvaných duchovních smyslů, jejichž kultivace hraje zcela zásadní roli v autenticitě a celistvosti naší duchovní zkušenosti i našeho jednání. Srov. TEDOLDI, Fabbio Massimo. La dottrina dei cinque sensi spirituali in San Bonaventura. 1. vydání. Roma: Antonianum, 1999.

79 Srov. např. BONAVENTURA. Sent. I, prooem., q. III, resp. (Opera Omnia. Quaracchi - Florentiae: Coll. S. Bonaventurae 1882, s. 12); POSPÍŠIL, Ctirad V. Soteriologie a teologie křže Bonaventury z Bagnoregia, s. 161-165. 
do „nemravnosti“. Není právě tohle nebezpečí vyhraněného kvietismu?º Jestliže by ale někdo zcela opomíjel „milost nazíráni“" a tak říkajíc stavěl „mravnost nade vše“, 81 pak mu bude zcela vážně hrozit „bez-božnost“, což by $\mathrm{v}$ určitém ohledu odpovídalo absolutizovanému a v mnoha ohledech sebestřednému „koženému asketismu“. Doufejme, že nevábnost obou alternativ bude sloužit jako pohnutka k nápravě toho, co na vztahu mezi dogmatickou a morální teologií prozatím ještě není tak docela v pořádku.

Ctirad Václav Pospíšil (1958), Katedra systematické teologie CMTF UP, Katedra fundamentální a dogmatické teologie KTF UK, Katedra systematické teologie, teologické etiky a teologické filozofie HTF UK

\section{ABSTRACT \\ CTIRAD VÁCLAV POSPÍŠIL Incentives to a Deeper Reflection on the Relation between Dogmatic and Moral Theology}

The topic of this study is the relationship between dogmatic and moral theology. In the first part of this paper the author defines this relationship as a hermeneutic circle and as an analogy of the trinitarian perichoresis. The second short chapter of this article is concerned with the issue of the natural and supernatural in the moral theology. In the third part the writer considers the relationship between Christ and the Torah. In the following paragraph we can see the relationship between the image of God and requests of moral theology. In the fifth short chapter we can find some inspirations of how to conceive of a new trinitarian moral theology. In the last point the author presents the thinking of Saint Bonaventura about theology of Sapientia that creates harmony between intellectus, affectus, contemplation and ethics.

\section{Key words}

theology, dogmatic theology, moral theology, ethics, philosophy of religion, Trinity

80 Srov. PACHO, Eulogio. Quietismo. In BORRIELO, Luigi - CARUANA, Edmondo DEL GENIO, Maria Rosaria (ed.). Dizionario di Mistica. 1. vydání. Citta del Vaticano: Libreria editrice vaticana, 1998 s. 1053-1055. Hodnocení těch, kdo byli odsouzeni jako kvietisté, je však dnes poněkud méně vyhraněné - srov. PEDRINI, Arnaldo. Gyuon Jeanne Marie. In Dizionario di Mistica, s. 620-621; ZOVATTO, Pietro. Fénelon Francesco. In Dizionario di Mistica, s. 499-500.

81 Jedna výborná starší česká filmová komedie pranýřující absolutizaci vnějškové mravnosti nesla právě tento název. 